\title{
RYSUNKI OSÓB NIEWIDOMYCH OD URODZENIA I OCIEMNIAŁYCH. STUDIUM PORÓWNAWCZE
}

Jedną z pierwszych technik twórczej ekspresji człowieka był rysunek. Teoretycy sztuki twierdzą, że podstawą rysunku jest percepcja rzeczywistości, a nauka rysowania zaczyna się od nauki świadomej obserwacji (Gill, 1997).

W niniejszym artykule traktuję rysunek jako wynik aktywności, w trakcie której niewidomy autor obrazuje określone zjawisko rzeczywistości poprzez swoją wizję zdobytą na podstawie wiedzy intersubiektywnej, niesionej poprzez język (Grabias, 2001) oraz na podstawie własnych, subiektywnych doświadczeń sensorycznych. W interpretację tego zjawiska autor wkłada własne emocje (negatywne, pozytywne) i własny sposób wykonania, który wynika ze sprawności rysunkowej ${ }^{1}$.

Jak zauważa V. Lowenfeld, dziecko, konstruując rysunek, nie obrazuje całej swojej wiedzy o przedmiocie, ale ukazuje to, co jest dla niego ważne w danym momencie (Lowenfeld, Brittain, 1977), a także nie stara się naśladować natury, choć z niej czerpie. Nie jest to patrzenie rejestrujące, ale selektywne. Sprawy dla dziecka istotne rysują mu się ostro i wyraziście, inne pozostają zaś niezauważone. Lowenfeld twierdzi, że „wygląd dziecięcego schematu jest uzależniony od tego, w jaki sposób dziecko odbiera dany obiekt, jaki ma do niego stosunek emocjonalny, jakie wrażenia kinestetyczne lub dotykowe $\mathrm{z}$ nim wiąże. Schemat jest zatem zbiorem wiedzy o danym przedmiocie" (Lowenfeld, Brittain, 1977, s. 89).

Dr Ewa Niestorowicz - Instytut Sztuk Pięknych, Wydział Artystyczny Uniwersytetu Marii Curie-Skłodowskiej w Lublinie, adres do korespondencji: Instytut Sztuk Pięknych UMCS, Al. Kraśnicka 2b, 20-718 Lublin; e-mail: ewaniestorowicz@poczta.umcs.lublin.pl

${ }^{1}$ Analogiczną interpretację procesu twórczego odnajduję w najważniejszych w naszej literaturze pracach: Popek S. (2001, s. 101-120); Hohensee-Ciszewska H. (1976, s. 60-70); Morawski S. (1961, s. 17-36); Wallis M. (1968,s. 63-75); Nęcka E. (1995); Pietrasiński Z. (1969, s. 10-15). 


\section{RYSUNEK JAKO WSPOMAGANIE ROZWOJU}

Rysowanie przez osoby niewidome poszerza ich wiedzę o świecie, utrwalając „bezwzrokowe struktury poznawcze - umiejętności poznawania i rozpoznawania przedmiotów dotykiem" (Chojecka, Magner, Szwedowska, Więckowska, 2008, s. 56). Ma także wpływ na rozwój wyobraźni i orientacji przestrzennej: rozwija pojęcia przestrzenne, poprzez wykonywanie operacji mających na celu określenie położenia przedmiotów w przestrzeni pomaga ustalać relację między obiektami (Chojecka i in., 2008, s. 6), sprzyja usprawnianiu zdolności manualnych, a także wyzwala radość tworzenia.

\section{OBRAZOWANIE TRÓJWYMIAROWYCH ZJAWISK RZECZYWISTOŚCI NA DWUMIAROWEJ PŁASZCZYŹNIE}

Badania nad wyobrażeniami wzrokowymi osób niewidomych budzą ogromne spory, pewne jest, że wyobrażenia te mają charakter przestrzenny, co potwierdzają badania mózgu (Vanlierde et al. 2003, cyt. w Szubielska, 2010). Niektórzy badacze twierdzą, że doświadczenie wzrokowe nie jest fundamentalnym czynnikiem warunkującym zdolność kreowania reprezentacji na płaszczyźnie. Aby zobrazować obiekt, niewidomy musi dokonać całego szeregu operacji, takich jak: zbudowanie płaskiego konstruktu wyobrażającego trójwymiarowy przedmiot, umieszczenie go na dwuwymiarowej płaszczyźnie podobrazia, przeskalowanie przedmiotu i dostosowanie do wymiarów płaszczyzny obrazu.

Studia nad rozwojem plastycznym osób niewidomych (np. D’Angiulli, Maggi, 2003; Kennedy, 1993; 2003; Kennedy, Juricevic, 2003; 2006; Szubielska, Niestorowicz, 2013, 2016) dowodzą, że osoby te przechodzą przez analogiczne jak widzący stadia rozwoju plastycznego, które pojawiają się u osób z dysfunkcją wzroku z pewnym opóźnieniem (mało możliwe jest, zdaniem badaczy, osiągnięcie stadium realizmu wizualnego). Dostępna jest osobom niewidomym technika rysunkowa, jeśli tworzą wypukłe rysunki na folii mikrorowkowanej. Tłocząc kształty rysikiem i dotykiem, kontrolują swój zamysł twórczy (Piskorska, Krzeszowski, Marek, 2008).

Wiadomo, że wiedza o zjawiskach wpływa na to, jak są one postrzegane (Gregory, 1971). Niewidomi, którzy widzieli i stracili wzrok, odwołują się zapewne do wspomnień wizualnych. Interesuje mnie fakt, czy odmienne doświadczenia sensoryczne w poznawaniu świata, w przypadku osób ociemniałych i niewidomych od urodzenia, ujawnią różnice w obrazowaniu obiektów rzeczywistości. Badania opisane w niniejszym artykule będą próbą poszukiwania odpowiedzi na powyższe pytanie. 


\section{POSTĘPOWANIE BADAWCZE}

Badania tu zaprezentowane dotyczą wizerunków zjawisk rzeczywistości w rysunkach osób całkowicie niewidomych (od urodzenia) i osób ociemniałych, przedmiotem analizy jest więc sprawność rysunkowa tychże osób.

Badania dotyczą rysunków (na folii dla niewidomych), które poddałam analizie jakościowej, a narzędziem analizy stał się model wytworu plastycznego, który uwzględnia jego treść, formę oraz kreatywność (Niestorowicz, 2007; 2017). Wszystkie komponenty tworzenia zostały przeanalizowane w odniesieniu do etapów rozwoju rysunkowego według klasyfikacji rozwoju plastycznego dziecka w normie, zaproponowanych przez S. Szumana, V. Lowenfelda i W. Brittaina oraz G.H. Luqueta (Szuman, 1990; Lowenfeld, Brittain, 1977; Luquet, 2001).

Celem niniejszych badań jest zatem analiza sposobów ujmowania zjawisk w rysunkach osób niewidomych od urodzenia i ociemniałych, przy następującym założeniu badawczym: odmienne doświadczenia sensoryczne niewidomych od urodzenia i osób ociemniałych ujawnią różnice w obrazowaniu obiektów rzeczywistości.

Główny problem badawczy zostanie uszczegółowiony w następujących pytaniach:

- Jakie są podobieństwa i różnice w czynności rysowania wśród badanych: osób niewidomych od urodzenia i osób ociemniałych?

- Jakimi cechami estetycznymi (formą, niepowtarzalnością ujęcia, sposobem przejawiania emocji) odznaczają się rysunki tych osób?

- Czym różnią się obrazy zjawisk rzeczywistości w rysunkach badanych osób niewidomych i ociemniałych? Na jakie trudności napotykają niewidomi w konstrukcji rysunku na dwuwymiarowej płaszczyźnie?

Zastosowałam w badaniach autorską procedurę, która obejmuje następujące etapy:

1. Trening rysunku na folii: linia ciągła, linia przerywana, figury geometryczne.

2. Docieranie do wiedzy o zjawisku za pomocą rozmowy na temat sensorycznych doświadczeń badanego oraz wiedzy zdobytej drogą umysłową. Chcąc uzyskać tę wiedzę, korzystam z wywiadu, realizując scenariusz zakreślony następującymi pytaniami: Co/Kto to jest?; Jak wygląda?; Co robi?/Do czego służy?; Gdzie mieszka/Gdzie się znajduje?

3. Rysowanie: osoby niewidome wykonały dziewięć rysunków, zgodnie z zasadą stopniowania trudności.

4. Ocena rysunku przez autora:

4.1. Wartość estetyczna: Czy podoba ci się twój rysunek? 
4.2. Kreatywność: Czy uważasz swoje rysunki za oryginalne?

5. Analiza rysunków przeprowadzona na podstawie autorskiej ankiety skonstruowanej według wiedzy o sztuce, etapach rozwoju plastycznego dziecka (Szuman, 1990; Lowenfeld, Brittain, 1977; Luquet, 2001) oraz na podstawie oceny treści, formy, kreatywności (Niestorowicz, 2007; 2017)2 . Proponowane narzędzie badawcze będzie służyło do opisu możliwości i analizy sposobów ujmowania zjawisk w rysunkach ${ }^{3}$. Ankieta zawierająca wskaźniki obrazowania, które będą podlegać analizie, przybierze zatem następujący kształt:

I. Warstwa treści. Sądzę, że autor ma do dyspozycji dwa sposoby przedstawienia relacji, w jakiej pozostają obiekt rzeczywisty i rysunek: 1. prezentację rzeczywistości poprzez podobieństwo: rysunek staje się wówczas ikoną, np. portret osoby; 2. prezentację poprzez symbol: rysunek odsyła do treści ważnych dla całej społeczności lub dla jednostki (Niestorowicz, 2007, s. 197).

II. Warstwa formy. Interesują mnie następujące wskaźniki obrazowania związane $\mathrm{z}$ formą analizowanego dzieła: 1. Ujęcie zjawiska, 1.1. umiejętność łączenia elementów obiektu w całość, 1.2. relacje części zjawiska w stosunku do całości: a) ilość narysowanych części, b) proporcje własne poszczególnych elementów w obrębie zjawiska, 2. Kontur, 3. Kształt: a) liniowy, b) geometryczny, 4. Przestrzeń, 4.1. komponenty przestrzeni: a) wskaźniki wielkości, 4.2. organizacja przestrzeni, 5. Kompozycja, 5.1. przestrzenność - miejsce poszczególnych komponentów rysunku w przestrzeni, 5.2. rozmieszczenie poszczególnych elementów obrazowanego zjawiska, 6 . Ruch w rysunku.

III. Warstwa kreatywności i emocjonalności wytworu. Warstwę tę oceniają osoby badane pod względem: 1. Oceny wartości estetycznych rysunku, 2. Kreatywności.

\section{Grupa badana}

Grupę badaną stanowiło 41 osób całkowicie niewidomych, w normie intelektualnej, w różnym wieku (w tym 34 osoby stanowiły grupę niewidomych od urodzenia, natomiast 7 osób to osoby ociemniałe, które straciły wzrok w późniejszym okresie życia) ${ }^{4}$.

\footnotetext{
${ }^{2}$ Model ten stanowi zmienioną, przystosowaną do oceny rysunku autorską wersję ankiety oceniającą rzeźbę głuchoniewidomych zawartą w moich książkach (Niestorowicz, 2007; 2017).

${ }^{3}$ Analizy te zostaną porównane i zweryfikowane zgodnie $\mathrm{z}$ etapami rozwojowymi człowieka oraz etapami możliwości rysunkowych dzieci widzących. Ustalam je korzystając z badań Szumana (1990), Lowenfelda i Brittaina (1977) oraz Luqueta (2001).

${ }^{4}$ Należy podkreślić, że grupa osób całkowicie niewidomych bez dodatkowych niepełnosprawności i w normie intelektualnej stanowi populację bardzo nieliczną, fakt ten stanowił zatem główne kryterium wyboru osób badanych.
} 
Badania zostały przeprowadzone w Specjalnym Ośrodku Szkolno-Wychowawczym dla Dzieci i Młodzieży Niepełnosprawnych im. Prof. Zofii Sękowskiej w Lublinie, w Specjalnym Ośrodku Szkolno-Wychowawczym dla Dzieci Niewidomych i Słabowidzących w Krakowie, w Specjalnym Ośrodku Szkolno-Wychowawczym dla Dzieci i Młodzieży Słabo Widzącej i Niewidomej im. Louisa Braille’a w Bydgoszczy. Uczestniczyli w nich także niewidomi studenci Katolickiego Uniwersytetu Lubelskiego Jana Pawła II. W niniejszym artykule prezentuję i omawiam rysunki czterech osób całkowicie niewidomych: dwóch osób niewidomych od urodzenia i dwóch osób ociemniałych. Głównym kryterium wyboru osób badanych w niniejszej publikacji stanowił stopień dysfunkcji zmysłu wzroku oraz podobny wiek badanej młodzieży. Dodatkowe kryterium stanowiła wcześniejsza styczność wszystkich osób badanych z rysunkiem. Tematem są rysunki postaci psa.
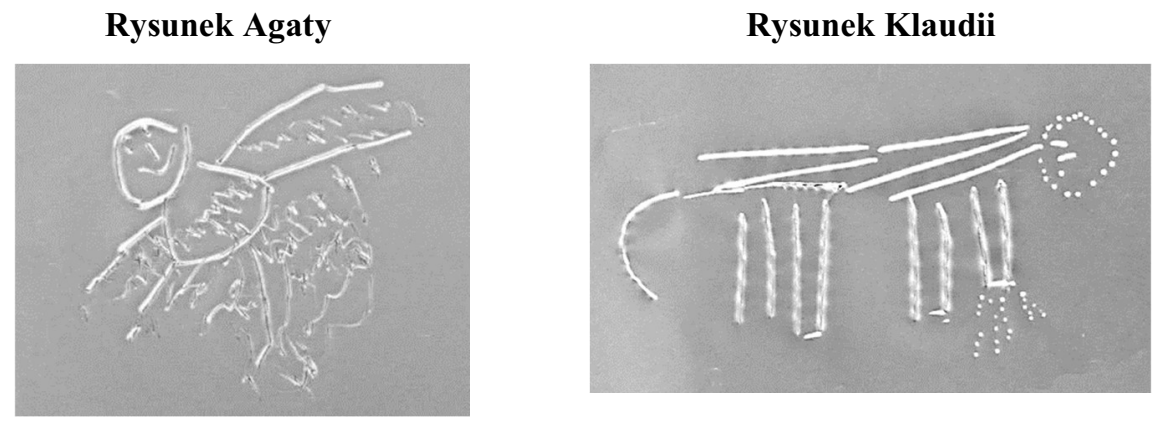

Rys. 1. Rysunki osób niewidomych od urodzenia

Rysunek Jarka

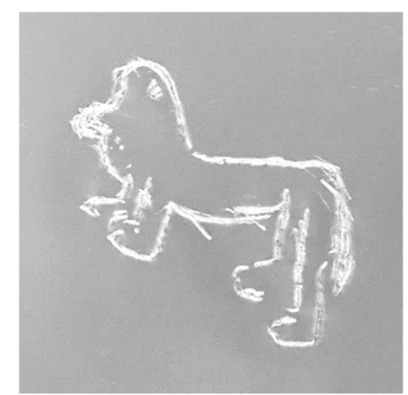

Rysunek Mateusza

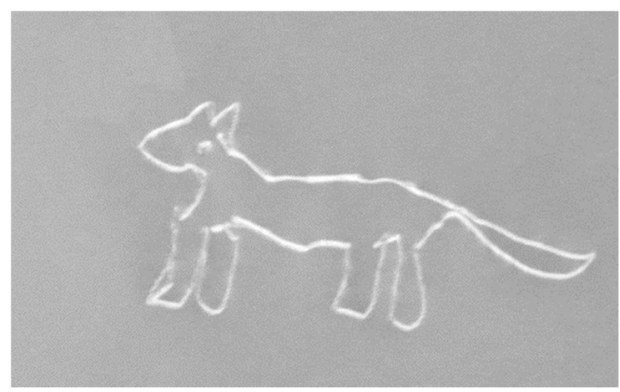

Rys. 2. Rysunki osób ociemniałych ${ }^{5}$

\footnotetext{
${ }^{5}$ Wszystkie zaprezentowane rysunki zostały wykadrowane ze względu na większą czytelność dla odbiorcy.
} 


\section{Analiza rysunków}

Osoby badane: Klaudia - 20 lat, Agata - 20 lat. Obie są całkowicie niewidome od urodzenia, chodzą do technikum. Jarek - 20 lat, jest osobą ociemniałą we wczesnym dzieciństwie. Deklaruje brak wspomnień wizualnych. Jest uczniem liceum. Mateusz - 17 lat, jest także osobą ociemniałą, nie widzi od 11 roku życia. Uczęszcza do technikum.

Wszyscy mają okazjonalną styczność z rysunkiem, oprócz Jarka, który uczęszcza na kółko plastyczne, pozostałe osoby nie praktykują regularnie żadnej aktywności plastycznej.

\section{Uwagi badanych podczas rysowania}

Tematem rysunku jest postać psa.

Agata: Najpierw głowa, krzywo wyjdzie, mi ten pies. Ten pies jakby był trochę rozkraczony i ogon miał taki skręcony.

Jarek: Też będę rysował psa? A jak ja mam psa narysować?

Klaudia: Jarek, jak wygląda pies? (pyta kolegi).

Jarek: Ma 4 łapy, ogon, futrzany jest, ale ja takiego nie narysuję.

Agata: Jak mam mu narysować pyszczek? Zrobię mu taki uśmiech, oczy to pewnie mi nie wyjdą.

Jarek: Dobrze, będę rysował psa, wyjdzie, jak wyjdzie. Ale też nie wiem, jak mu narysować pyszczek.

Agata: Futro rysuję, nie wiem jak. Pies jest chyba najtrudniejszy do narysowania. A pazurki też narysować?

Agata: Na łapach przydałoby się jakieś futro. Na grzbiecie też. Łapy mu całkowicie zasłoniłam futrem.

Klaudia: Przypomina to w ogóle psa? Brzuszek ma bokiem i łapki też bokiem. A tutaj ma ogon (Klaudia pokazuje poszczególne części ciała psa).

Agata: Mój pies jest zupełnie futrzany.

Jarek: Nie wiem, czy ten pies wyszedł, nie wiem też, jaka to rasa.

Agata: Mi wyszedł bardziej jak niedźwiedź. Futerkowy piesek. Jaki pyszczek ma fajny! Są takie psy, co przypominają niedźwiedzia. Jestem z niego zadowolona.

Klaudia: Mój pies wygląda jak zwykły pies. Ma głowę, dwie łapy, przy łapach pazurki, przynajmniej tak to miało wyglądać, ogon zawinięty. A tutaj miały być oczy i nos, ale mi nie wyszło. (Na pytanie: czemu nie ma uszu? Klaudia odpowiada, że zapomniała narysować. Stwierdza, że pies jej wyszedł ładniejszy niż człowiek).

Jarek: Mój pies jest odwrócony w jedną stronę - tak profilowo, ma dwie pary nóg, przednie zachodzą na tylne.

E.N.: Jesteś zadowolony z rysunku? 
Jarek: Mój psiaczek jest super. Mój pierwszy zwierzaczek, którego narysowałem, widać, że przyjaciel człowieka. Jestem bardzo zadowolony, myślałem, że gorzej wyjdzie.

Mateusz: Dobrze, narysuję psa, tylko jak? Jeszcze nigdy nie rysowałem zwierzaka.

E.N.: Mateusz, jak wygląda pies?

Mateusz: Ma cztery łapy, ogon, uszy.

Mateusz: Bardziej mi wyszedł kot niż pies, ale jest nie tak źle, jak myślałem.

E.N.: Jesteś zadowolony z rysunku?

Mateusz: Biorąc pod uwagę fakt, że pierwszy raz rysowałem psa, sądzę, że wyszedł nawet ładnie. Tak, jestem bardzo zadowolony.

\section{Warstwa pierwsza - treść}

\section{Sposób ujęcia rzeczywistości}

Rysunki stanowią uproszczoną ikonę rzeczywistości, zawierającą prototypowe wyobrażenie zjawiska ${ }^{6}$, mają cechy schematu. W przypadku rysunków osób niewidomych od urodzenia jest to schemat ogólny- uproszczony. Rysunki osób ociemniałych natomiast zawierają elementy schematu wzbogaconego.

\section{Warstwa druga - forma}

\section{Ujęcie zjawiska}

1.1. Umiejętność łączenia elementów obiektu w całość.

Synteza całości: rysunki są syntetyczne, a poszczególne elementy połączone w całość. Rysunek przedstawia pełną postać obrazowanego obiektu, choć uproszczoną.

1.2. Relacje części zjawiska w stosunku do całości (proporcje, rozmieszczenie części w całości):

a) Ilość narysowanych części:

Wszystkie cztery rysunki postaci psa mają tylko najbardziej charakterystyczne części ciała, narysowane zgodnie z rysunkami okresu schematycznego. Rysunki Agaty i Klaudii ukazują geometryczną głowę, osadzoną bezpośrednio na tułowiu, który w rysunku Klaudii jest wielokrotnie powtórzoną linią. Natomiast w rysunku Agaty tułów zbliżony jest swym kształtem do elipsy. Rysunki Jarka i Mateusza odchodzą już od geometrii kształtów i ukazują próby różnicowania postaci.

\footnotetext{
${ }^{6}$ Wzorzec ten odnoszę do wzorca zgodnego z etapami rozwoju rysunkowego dzieci widzących, korzystając z badań Szumana (1990), Lowenfelda i Brittaina (1977) oraz Luqueta (2001).
} 
Wszystkie przedstawione postacie psa posiadają po cztery łapy i ogon. Na trzech rysunkach (Agaty, Klaudii i Jarka) pies nie posiada uszu, bo badani o nich zapomnieli.

b) Proporcje poszczególnych elementów w obrębie całości.

Wszystkie wizerunki psa są uproszczone, a ich części stosunkowo proporcjonalne względem całości rysunku.

\section{Kontur}

Kontur postaci narysowanej przez Agatę i Klaudię posiada cechy geometryczności, ale odznacza się indywidualnym stylem każdej z autorek.

Kontur rysunku Klaudii jest zdecydowany, kreślony pewnymi pociągnięciami rysika. Autorka nie stara się go różnicować, czasem korzysta z tzw. brajlowskiej metody rysowania, czyli budowania linii za pomocą punktów. Kontur rysunku Agaty również posiada cechy geometryczności, choć autorka stara się różnicować pociągnięcia. Linie konturu obu dziewcząt posiadają podobną grubość i podobną siłę nacisku narzędzia rysunkowego, zazwyczaj zamykają poszczególne elementy postaci i są rozplanowane zgodnie z okresem schematu.

Kontur zaprezentowany przez Jarka jest zróżnicowany, odznacza się wielokrotnymi pociągnięciami, które budują bryłę postaci. W niektórych partiach autor konstruuje postać delikatnymi pociągnięciami, o różnej sile nacisku i różnej grubości. Linie kreślone są pewnymi pociągnięciami. Z pewnością kontur wykonany przez Jarka można za Szumanem nazwać ,,żywym konturem” (Szuman,1990, s. 43) - odchodzi od geometrii, rysownik poszukuje większego zróżnicowania kształtów. Kontur zaproponowany przez Mateusza nie jest aż tak zróżnicowany jak kontur Jarka, ale nie posiada już cech geometryczności. Charakteryzuje się delikatnymi pociągnięciami, za pomocą których autor dokonuje próby zróżnicowania kształtów.

\section{Ksztalt}

W badanych rysunkach Agaty i Klaudii występuje uproszczony kształt geometryczny, który charakteryzuje się zmniejszoną ilością elementów i zmianą proporcji. W rysunkach można zatem zaobserwować kształt:

a) liniowy:

- budowany punktowo - oczy psa w rysunku Klaudii, owal głowy wybity punktami za pomocą rysika,

- wydłużony - budowany na linii - łapy w rysunku Agaty, rytmicznie przedstawiony tułów w rysunku Klaudii. 
b) geometryczny:

- owalny - budowany na kole - głowy w obu rysunkach (w rysunku Klaudii owal jest skonstruowany za pomocą punktów, tułów w rysunku Agaty ma postać zniekształconej elipsy),

- wielokątny - budowany na prostokącie - łapy w rysunku Klaudii. Trzy łapy domknięte są tylko z jednej strony, jedna w ogóle się nie domyka.

Wymienione powyżej kształty są charakterystyczne dla schematów uproszczonych.

Natomiast w rysunku Jarka występują już kształty zdecydowanie odchodzące od geometrii, zróżnicowane, ukazujące bogatsze rozwiązania. Linia jest bardziej giętka i płynna, widać zarys sylwetki, choć kształt schematu jest jeszcze ogólny, ale już wiadomo, że obrazuje psa, który nie posiada jeszcze cech typowych, charakterystycznych dla okresu poschematycznego. Nie możemy określić np. jaka to rasa, może to być dowolny pies. Rysunek więc nadal jest schematyczny, ale o cechach schematu wzbogaconego i odpowiednich proporcjach. Podobnie Mateusz proponuje już sposób odbiegający od geometrycznego. Szuka rozwiązań bardziej zróżnicowanych i bogatszych, zdecydowanie sylwetowych. Jednak choć w jego przedstawieniu widać, że postać jest zwierzęciem, to jeszcze nie wiadomo jakim rysunek równie dobrze może przedstawiać kota lub lisa.

\section{Przestrzeń}

4.1. Komponenty przestrzeni

a) Wskaźniki wielkości:

Rysunek Klaudii jest dość duży, ale jest rozmieszczony niesymetrycznie. Narysowała tułów czterema rytmicznymi liniami, które określającą grubość psa. Rysunek przypomina pierwsze schematy przedstawień zwierzęcych właściwych dzieciom widzącym. Postać psa narysowana przez Agatę, Mateusza i Jarka wydaje się być mała na dużej przestrzeni kartki. W rysunku Agaty postać jest rozmieszczona niesymetrycznie. Rysunek Jarka rozmieszczony jest w części środkowej kartki, natomiast Mateusza na samym dole obrazowanej powierzchni.

\subsection{Organizacja przestrzeni}

Rysunek psa autorstwa Klaudii jest przekształceniem schematu człowieka. Ukazuje frontalnie narysowaną głowę, jednak tułów ujęty jest profilowo (bokiem), inaczej niż w schemacie postaci człowieka. Łapy zwierzęcia także przedstawione są z profilu. Mamy więc do czynienia z kilkoma punktami widzenia, co jest charakterystyczne dla okresu schematu u dzieci widzących. Co ciekawe, rysunek Klaudii ukazuje typowe przedstawienie postaci psa właściwe dzieciom widzącym. Dzieci, obrazując zjawiska, dokonują selekcji i wybierają najbardziej 
charakterystyczne ujęcia w tzw. perspektywie kanonicznej ${ }^{7}$. Podobnie postępują osoby niewidome. W rysunku Agaty tułów psa i łapy ukazane są za pomocą rzutu prostokątnego z góry, natomiast głowa przedstawiona jest frontalnie. Jest to widok przedstawiany często przez osoby niewidome. Obrazuje on drogę poznania dotykowego: głaskają psa po grzbiecie i odnajdują cztery łapy. W wizualizacji wszystkie łapy doczepiają do tułowia - rozchodzą się po dwie z każdej strony. Głowa natomiast zawsze przedstawiana jest $\mathrm{w}$ widoku frontalnym. Na badanych rysunkach obserwujemy więc kilka punktów widzenia: tułów i łapy widziane od góry w postaci rozklejonej makiety, głowa (zapożyczona ze schematu człowieka) przedstawiona frontalnie, ale zwrócona przodem do odbiorcy.

Postać psa zobrazowana przez Jarka przedstawiona jest profilem, zgodnie z konwencją dzieci widzących, będących już w okresie schematu wzbogaconego. Co więcej, autor wprowadza elementy wskaźników głębi: przedstawia łapy za pomocą interpozycji ${ }^{8}$, a także zmniejsza elementy oddalone (tylne łapy). Stosuje więc środki przedstawienia przestrzeni charakterystyczne dla osób widzących. Rysunek Mateusza zawiera również ujęcie profilowe, ale autor nie używa wskaźników głębi.

Wszystkie badane postacie są dwuwymiarowe, nie uwzględniają perspektywy (poza zjawiskiem zmniejszania się dalszych elementów w rysunku Jarka), nie posiadają planów, nie uwzględniają także linii podstawy.

\section{Kompozycja - miejsce obrazu w przestrzeni}

5.1. Przestrzenność - miejsce poszczególnych komponentów rysunku w przestrzeni

Postać psa narysowana przez Agatę rozmieszczona jest w prawej części kartki, pozostała część jest niezagospodarowana. Rysunek Klaudii natomiast przedstawia symetrycznie narysowaną postać, jednak asymetrycznie rozmieszczoną na podobraziu (z prawej strony). Oba rysunki nie stanowią kompozycji centralnej. Rysunki Jarka i Mateusza przedstawiają także nieduże postaci psa, ale zakomponowane na środku kartki.

5.2. Rozmieszczenie poszczególnych elementów obrazowanego zjawiska

Badane rysunki są syntetyczne, poszczególne części ciała psa są uproszczone. Postać psa w rysunku Klaudii jest rozmieszczona zgodnie z rysunkiem z fazy schematu uproszczonego. Jedynie głowa psa doczepiona jest do tułowia częścią górną, w taki sposób, że dolna jej część nie kieruje się ku linii podstawy, tylko ku

\footnotetext{
${ }^{7}$ Perspektywa kanoniczna - obrazowany przedmiot przedstawiany jest w najbardziej typowym, charakterystycznym dla niego widoku (zob. Francuz, 2013).

${ }^{8}$ Interpozycja „oznacza wzajemne przysłanianie się nietransparentnych obiektów, położonych w głąb oglądanej sceny wizualnej. Obiekt przysłonięty jest spostrzegany jako znajdujący się dalej od obserwatora niż obiekt, który go przysłania" (zob. Francuz, 2013).
} 
krawędzi prawego boku rysunku. Pojawia się więc problem natury orientacji przestrzennej. Niektóre elementy, zgodnie z okresem schematycznym, są pomijane. W rysunku Agaty postać ukazana jest w specyficznych dla dzieci niewidomych ujęciach (z góry i w przedstawieniu frontalnym). Jarek i Mateusz natomiast obrazują postać profilowo, w charakterystycznym ujęciu dla rysunków dzieci widzących, znajdujących się na etapie schematu wzbogaconego. W rysunkach obu badanych pojawia się problem z rozmieszczeniem oka, co zdarza się osobom niewidzącym w związku z trudnością wyczuwania małych powierzchni.

\section{Ruch w rysunku}

Wszystkie badane rysunki przedstawiają postać psa w bezruchu.

\section{Warstwa trzecia - kreatywność i emocjonalność wytworu}

1. Ocena wartości estetycznych rysunku (ocenia osoba badana)

Wszystkie badane osoby miały obawy, czy rysunki będą dobre. Jednak, kiedy oglądali je po zakończeniu czynności rysowania, stwierdzili, że są zadowoleni $\mathrm{z}$ efektu końcowego.

\section{Kreatywność}

Badani nie uważają swoich rysunków za oryginalne przedstawienia. Narysowali postać psa tak, jak ją sobie wyobrażają.

\section{Moja interpretacja problemu}

Wszystkie rysunki z pewnością wykazują cechy charakterystyczne dla okresu schematu (ideoplastyki) dzieci widzących, według Szumana (1990) okres ten występuje między 3 a 12 rokiem życia. Klasyfikacja Lowenfelda (1977) uwzględnia także stadium schematyczne, ale wyznacza je na 7-9 rok życia, w typologii Luqueta (2001) natomiast należy wziąć pod uwagę końcowe stadium realizmu intelektualnego i początek realizmu wizualnego, który zaczyna się około 7/8 roku życia (Schaffer, 2005).

Faktycznie trudno jest jednoznacznie przyporządkować badane rysunki do określonego etapu rozwoju plastycznego według klasyfikacji zaprezentowanych przez Lowenfelda czy Luqueta, ponieważ rysunki osób ociemniałych zawierają także cechy charakterystyczne dla następnego już etapu: początki realizmu według Lowenfelda (9-12 rok życia); realizmu wizualnego według Luqueta (od 8/9 roku życia). Podział Szumana jest pod tym względem szerszy, bo stadium schematyczne obejmuje większy przedział wiekowy. 
W rysunkach osób niewidomych następuje bez wątpienia spore opóźnienie, ale co ciekawe, mimo opóźnienia rozwój ten przebiega podobnie jak u osób widzących. Należy jednak zauważyć, że rysunki zawierają zarówno prototypowe wyobrażenie uspołecznione o cechach schematu ogólnego, jak i wyobrażenia subiektywne, zbudowane na bazie swoistych wyobrażeń i indywidualnych doświadczeń sensorycznych.

Rysunek psa skonstruowany przez Klaudię przypomina przekształcony schemat człowieka, ponieważ tułów ukazany jest profilowo, podobnie jak łapy, ale głowa narysowana jest frontalnie. Ujawnia się zatem układ z kilkoma punktami widzenia, co jest również charakterystyczne dla okresu schematu dzieci widzących, które w podobny sposób obrazują postaci zwierząt. Tak przedstawiony układ jest wręcz prototypowy i stanowi, zdaniem Szumana, początkową formę schematu zwierząt (Szuman, 1990, s. 39). Różnicę stanowi ułożenie głowy psa. Klaudia zaprezentowała co prawda widok frontalny, ale głowa doczepiona jest do tułowia częścią górną, w taki sposób, że dolna jej część nie kieruje się ku linii podstawy, ale ku krawędzi prawego boku rysunku.

W rysunku Agaty tułów psa i łapy ukazane są za pomocą rzutu prostokątnego z góry, a głowa frontalnie. Jest to widok budowany często przez dzieci niewidome, który ukazuje drogę poznania dotykowego: dzieci głaskają psa od góry i oglądają dotykiem jego cztery łapy. Próbują je doczepić do tułowia (łapy rozchodzą się w różnych kierunkach po dwie z każdej strony $)^{9}$. Głowa psa natomiast zawsze przedstawiana jest $\mathrm{w}$ układzie frontalnym, układ głowy zatem zgadza z projekcją dzieci widzących w okresie schematu (Szuman, 1990, s. 39).

Agata wprowadziła do rysunku psa długą sierść. Specyficzne przedstawienie postaci psa, a także przykrycie go futrem, może spowodować trudności w identyfikacji zwierzęcia. Identyfikacja jest zatarta również poprzez fakt, że postacie na obydwu rysunkach nie posiadają uszu, bo badane o nich zapomniały. Oba badane rysunki przedstawiają kształty geometryczne, a także geometryczny kontur, regularny, lecz ogólnikowy (Szuman, 1990).

${ }^{9}$ Lowenfeld taki sposób przedstawienia przedmiotów nazywa układem za pomocą „zaginania” (folding over), natomiast Luquet nazywa je rysunkiem w postaci „rozłożenia” (folding-out). Są to sposoby przedstawień, którymi posługują się także dzieci widzące, będące w okresie schematycznym; jest to najczęściej sposób obrazowania przestrzeni, otoczenia, np. krajobrazu, choć zdarzają się przedstawienia także wybranych przedmiotów. Przestrzeń przypomina rozłożoną makietę, a niektóre obiekty przedstawione są do góry nogami. U dzieci niewidomych takie schematy ujawniają się często przy obrazowaniu pojedynczych obiektów, np. psa i stołu, czasem domu, ma to z pewnością związek z dotykowym schematem poznawczym charakterystycznym dla dzieci niewidomych, ale sposób radzenia sobie z obrazowaniem przedmiotów na płaszczyźnie jest podobny. 
Wymienione powyżej cechy są charakterystyczne dla schematów uproszczonych.

Rysunki osób ociemniałych także prezentują okres schematyczny, ale o pewnych cechach schematu wzbogaconego. Widzimy swoiste cechy danego przedmiotu i zjawiska o bardziej odpowiednich proporcjach (Szuman, 1990; Lowenfeld, 1977). Występuje już kontur i kształty zdecydowanie odchodzące od geometrii, zróżnicowane (bardziej giętkie i płynne, a także już sylwetkowe). W rysunku Jarka pies nie posiada jeszcze cech typowych (charakterystycznych dla okresu poschematycznego), nie można np. stwierdzić, jaka to rasa. W rysunku Mateusza mamy jeszcze problem z identyfikacją zwierzaka - postać równie dobrze może przedstawiać psa, kota lub lisa.

Obie postacie psa zaprezentowane przez chłopców są przedstawieniami profilowymi, tak jak ujęcia dzieci widzących będących już w okresie schematu wzbogaconego. Profil u dzieci widzących pojawia się po 7 roku życia (Szuman, 1990, s. 39) ale dopiero po 9 roku życia następuje pełne przedstawienie profilowe - staje się ono częstsze od frontalnego widoku lica.

W rysunku Jarka wprowadzone są elementy wskaźników głębi, łapy przedstawione są za pomocą interpozycji, a także zmniejszone są te elementy, które są oddalone (tylne łapy). Stosuje więc środki budowania przestrzeni zgodnie z konwencją charakterystyczną dla osób widzących. Rysunki osób ociemniałych charakteryzują się lepszym orientowaniem się w przestrzeni kartki.

Postacie we wszystkich czterech badanych rysunkach są dwuwymiarowe, nie uwzględniają perspektywy (poza zjawiskiem zmniejszania się dalszych elementów w rysunku Jarka), a także nie posiadają planów. Co ciekawe, w żadnym badanym rysunku nie występuje otoczenie. Na podobraziu istnieje tylko przedmiot, bez linii podstawy (charakterystycznej dla dzieci widzących). Być może jest to wynikiem styczności osób niewidomych z ilustracją czy grafiką dotykową. Jedną z najważniejszych zasad tyflo-ilustracji jest synteza przedstawienia, która powinna zawierać wyważoną ilość przedmiotów i informacji. Zbyt wiele elementów wprowadza chaos, powodując nieczytelność rysunku. Dzieci niewidome przyzwyczajone są do ilustracji dotykowych zgodnie z zasadą , co w tekście, to na ilustracji” (np. w scenie z bajki o Czerwonym Kapturku, jeśli jest mowa o babci i wilku, ilustracja powinna przedstawiać babcię, wilka i nic więcej, każdy dodany szczegół będzie burzył przekaz i odbiór dotykowy). Badane rysunki charakteryzują się taką właśnie syntezą przedstawienia. Autorzy poproszeni o narysowanie psa przedstawili wyłącznie wymagany obiekt.

Jak zauważa Schaffer (2005), dzieci niewidome, bez regularnego ćwiczenia rysunku, nie mają możliwości przyswojenia konwencji obrazowania osób widzą- 
cych, dla których pewne zjawiska, jak np. linia podstawy, są punktem odniesienia w przestrzeni.

\section{WNIOSKI}

Porównując rysunki badanych osób niewidomych od urodzenia z rysunkami osób ociemniałych, można z pewnością zaobserwować następujące różnice:

1. U osób niewidomych od urodzenia można zauważyć większe (niż u osób ociemniałych) zniekształcenie obrazowanych kształtów, zdarza się również brak trafienia w punkt albo brak domknięcia kształtu.

2. U osób niewidomych pojawiają się problemy z symetrycznym rozmieszczeniem niektórych elementów obiektu. Osoby ociemniałe realizują symetrię.

3. W rysunkach osób niewidomych od urodzenia występują uproszczone kształty geometryczne, które charakteryzują się zmniejszoną ilością elementów i zmianami proporcji. W rysunkach osób ociemniałych natomiast można zaobserwować kształty zdecydowanie odchodzące od geometrii, bardziej giętkie i płynne, zróżnicowane, szukające bogatszych rozwiązań, sylwetkowe.

4. Kontur w rysunkach osób niewidomych od urodzenia posiada cechy geometryczności, jest regularny, lecz ogólnikowy. Linie posiadają podobną grubość i podobną siłę nacisku narzędzia rysunkowego. Kontur osób ociemniałych odznacza się natomiast pociągnięciami, które płynnie budują bryłę postaci, odchodząc od geometrii. Autorzy poszukują większego zróżnicowania kształtów.

5. Obraz zjawiska u osób niewidomych od urodzenia często uwidacznia dotykową drogę poznawczą autora (rysunek Agaty).

6. W rysunku osoby ociemniałej (rysunek Jarka) pojawiają się środki budowania przestrzeni charakterystyczne dla osób widzących - wskaźniki głębi: interpozycja, a także zjawisko zmniejszania się tych elementów, które są bardziej oddalone.

Osoby niewidome od urodzenia, niestymulowane w zakresie aktywności rysunkowej były w stanie osiągnąć samoistnie etap schematów uproszczonych. Rysunki ich ociemniałych kolegów natomiast (nawet osoby deklarującej, że nie posiada żadnych wspomnień wizualnych) odznaczały się już cechami schematów wzbogaconych, charakteryzujących się podobną konwencją i przedstawieniem obiektów w sposób, w jaki konstruują je dzieci widzące, będące na tym etapie rozwoju rysunkowego.

Jak już zostało wspomniane, można zauważyć spore opóźnienie w rozwoju rysunkowym osób niewidomych $\mathrm{w}$ stosunku do ich widzących rówieśników. Zapewne dlatego, że aktywność rysunkowa jest dla osób niewidomych czynnością 
okazjonalną. Mimo to osoby niewidome z całą pewnością są w stanie uczestniczyć w akcie rysunkowego obrazowania świata.

Wydaje się, że etap schematu uproszczonego jest uniwersalnym wyposażeniem człowieka. Odmienności w prezentowaniu zjawisk dotyczą dróg percepcji. Być może kształcenie i stymulacja sprawności rysunkowej umożliwiłyby osobom niewidomym przejście do następnych stadiów rozwoju rysunkowego.

\section{BIBLIOGRAFIA}

Chojecka, A., Magner, M., Szwedowska, E., S. WięcKowsKa, E. FSK (2008). Nauczanie niewidomych dzieci rysunku. Laski: Towarzystwo Opieki nad Ociemniałymi.

D'Angiulli, A., MAgGi, S. (2003). Development of drawing abilities in a distinct population: Depiction of perceptual principles by three children with congenital total blindness. International Journal of Behavioral Development, 27(3), 193-200.

FrancuZ, P. (2013). Imagia. W kierunku neurokognitywnej teorii obrazu. Lublin: Wydawnictwo KUL. GILL, R. (1997). Zasady rysunku realistycznego. Łódź: Galaktyka.

GRABIAS, S. (2001). Język w zachowaniach spolecznych. Lublin: Wydawnictwo UMCS.

Gregory, R.L., (1971). Oko i mózg. Psychologia widzenia. Warszawa: PWN.

HoHENSEe-CiszewsKa, H. (1976). Podstawy wiedzy o sztukach plastycznych. Warszawa: WSiP.

Kennedy, J.M. (1993). Drawing and the blind: Pictures to touch. New Haven, CT: Yale University Press.

KenNeDY, J.M., JuRICEVIC, I. (2003). Haptics and projection: Drawings by Tracy, a blind adult. Perception, 32(9), 1059-1071.

KenNedy, J.M., JuRICEVIC, I. (2006). Blind man draws using diminution in three dimensions. Psychonomic Bulletin \& Review, 13(3), 506-509.

LuQuet, G.H. (2001). Children's Drawings/Le Dessin Enfantin. London: Free Association Books.

LOWENFELD, V., BRITTAIN, W.L. (1977). Twórczość a rozwój umysłowy dziecka. Warszawa: PWN.

MoraWSKI, S. (1960). O realizmie jako kategorii artystycznej. Etyka, 2, 17-36.

NĘCKA, E. (1995). Proces twórczy i jego ograniczenia. Kraków: Wydawnictwo Impuls.

Niestorowicz, E. (2007). Świat w umyśle i rzeźbie osób gluchoniewidomych. Lublin: Wydawnictwo UMCS.

Niestorowicz, E. (2017). The World in the Mind and Sculpture of the Deafblind People. Cambridge, UK: CAMBRIDGE SCHOLARS Publishing.

PIETRASIŃSKI, Z. (1969). Myślenie twórcze. Warszawa: PZWS.

Piskorska, A., Krzeszowski, T., MareK, B. (2008). Uczeń z dysfunkcja wzroku na lekcji angielskiego. Wskazówki metodyczne dla nauczycieli. Warszawa: Uniwersytet Warszawski.

POPEK, S. (2001). Człowiek jako jednostka twórcza. Lublin: Wydawnictwo UMCS.

SZAFFER, R. (2005). Psychologia dziecka. Warszawa: PWN.

SzUBIELSKA, M. ( 2010), Zdolności wyobrażeniowe niewidomych dzieci w zakresie skaningu i rotacji kształtu dotykanych obiektów, Roczniki Psychologiczne, 13(2), 145-160.

SzUBIELSKA, M., NiEstorowicz, E. (2013). Twórczość plastyczna jako forma wspierania rozwoju osób niewidomych i głuchoniewidomych. W: D. MüLLER, A. SoBCZAK (red.), Rozwój i jego wspieranie $w$ perspektywie rehabilitacji i resocjalizacji (s. 89-104). Łódź: Wydawnictwo Uniwersytetu Łódzkiego. 
Szubielska, M., Niestorowicz, E., MAReK, B. (2016). Jak rysują osoby, które nigdy nie widziały? Badania niewidomych uczniów. Roczniki Psychologiczne, 19(4), 659-680.

Szuman, S. (1990). Sztuka dziecka: psychologia twórczości rysunkowej dziecka. Warszawa: WSiP.

WaLlis, M. (1968). Dzieje sztuki jako dzieje struktur semantycznych. Kultura i Spoleczeństwo, 12(2), 63-75.

\title{
RYSUNKI OSÓB NIEWIDOMYCH OD URODZENIA I OCIEMNIAŁYCH. STUDIUM PORÓWNAWCZE
}

\author{
Streszczenie
}

Badania zaprezentowane w niniejszym artykule dotyczą wizerunków zjawisk rzeczywistości w rysunkach osób całkowicie niewidomych (od urodzenia) i osób ociemniałych. Przedmiotem analizy jest sprawność rysunkowa i jej rozwój.

Badania dotyczyły wypukłych rysunków na folii dla niewidomych. Poddałam je analizie jakościowej, a narzędziem analizy stał się model wytworu plastycznego, który uwzględnia jego treść, formę oraz kreatywność. Wszystkie komponenty tworzenia zostały przeanalizowane w odniesieniu do etapów rozwoju rysunkowego według klasyfikacji rozwoju plastycznego dziecka w normie zaproponowanych przez S. Szumana, V. Lowenfelda, W. Brittaina, oraz G.H. Luqueta.

Cel badań zawiera się w pytaniu, czy odmienne doświadczenia sensoryczne niewidomych od urodzenia i osób ociemniałych ujawnią różnice w obrazowaniu obiektów rzeczywistości?

Slowa kluczowe: osoby niewidome; osoby ociemniałe; rysunek; etapy rozwoju plastycznego; model wytworu plastycznego.

\section{DRAWINGS OF THE BLIND FROM BIRTH AND LATE BLIND PEOPLE. A COMPARATIVE STUDY}

\section{S u m mary}

The results of the research presented in the article concern the visions of reality and its various phenomena in drawings of completely blind people (congenitally) and late blind people. The focus of my analysis was drawing skills and their development.

The research concerned convex drawings on foil for blind people. I conducted a qualitative analysis of the drawings. The main tool for my analysis was the model of the structure of an artistic piece taking into account the work's content, form and creativity. All components of the creative process were analysed with reference to the subsequent stages of drawing development in accordance with the classification of the child's artistic development within intellectual norm, as indicated by S. Szuman, V. Lowenfeld, W. Brittain and G.H. Luquet.

Key words: blind people; late blind people; drawing; stages of artistic development; model of the structure of an artistic piece. 